\title{
The effect of breed on the relationship between feed composition and the efficiency of protein utilization in pigs
}

\author{
BYI. KYRIAZAKIS, D. DOTAS AND G. C. EMMANS \\ Genetics and Behavioural Sciences Department, SAC Edinburgh, West Mains Road, \\ Edinburgh $\mathrm{EH} 9 \mathrm{JJG}$
}

(Received 8 December 1992 - Revised 4 August 1993 - Accepted 23 September 1993)

\begin{abstract}
The objective of the present experiment was to test whether the relationship between feed composition and the efficiency of protein utilization in pigs was different between two very different breeds. Fortyeight entire male pigs, half Large White $\times$ Landrace $(L W \times)$ and half Chinese Meishan $(C M)$, were assigned at $13 \mathrm{~kg}$ live weight either to an initial slaughter group or to one of six feeding treatments for 6 weeks. The two feeds used were starch, with $12.52 \mathrm{MJ}$ metabolizable energy (ME) and $0 \mathrm{~kg}$ digestible crude protein (DCP)/kg, and a high-protein feed, with $11.95 \mathrm{MJ}$ ME and 0.362 kg DCP/kg. In the first week the $\mathrm{LW} \times$ pigs were given $400 \mathrm{~g}$ high-protein feed/d with $0,100,200 \mathrm{or} 300 \mathrm{~g}$ starch/d, or $200 \mathrm{~g}$ high-protein feed/d with 400 or $500 \mathrm{~g}$ starch/d. The six diets had ME:DCP ratios of between 33 and $119 \mathrm{MJ} / \mathrm{kg}$. The diet compositions were held constant within each of the six treatments but the allowances were increased weekly on time-based linear scales to be $2 \cdot 25$ as great in week six as in week one. The allowances for the $C M$ pigs were 0.75 of those for the $L W \times$. The calculated efficiency of protein utilization, $e_{p}$, was found to be directly proportional, up to a maximum value, to the ME: DCP ratio of the diet for both breeds, as found previously for $L W \times$ male and female pigs. The overall constant of proportionality was $e_{p}=0.0108$ (SE 0.00024$) \mathrm{ME}: \mathrm{DCP}$, the value of which did not differ significantly between the two breeds. The maximum observed $e_{p}$ values were 0.710 (SE 0.014) and 0.824 (SE 0.016) for the $L W \times$ and $C M$ pigs respectively. It is likely that the lower maximum value for the $L W \times$ pigs was an experimental artefact due to increased feed spillage by these pigs on the two highest starch allowances used. In previous experiments the maximum value of $e_{p}$ was found to be 0.813 for $\mathrm{LW} \times$ pigs, a value similar to that found here for the CM pigs. The results are consistent with the view that the two very different pig breeds have the same net efficiency in using protein and use the same rules for partitioning a scarce resource such as energy.
\end{abstract}

Breeds: Efficiency of protein utilization: Energy intake: Meishan: Pigs

It has been observed (e.g. Campbell et al. $1985 a, b$ ) that the rate at which pigs retain protein can be increased, at a given rate of protein supply, by increasing the rate of supply of energy. One explanation of such findings is the that the pig 'values' some rate of positive lipid retention more highly than the achievement of an increased rate of protein retention and, therefore, some of the protein supply is used for lipid gain. Such a 'partitioning rule' explanation was particularly advocated by Whittemore (1983) who proposed that there was some minimum value for the lipid:protein ratio in the gain that the pig would not be prepared to go below. Such an explanation raises several difficulties, but it does open the possibility that different kinds (genotypes) of pigs could differ in the minimum value of the lipid:protein ratio in their gain that they would be prepared to accept. In order to predict the growth rate and the composition of the gain of a pig on a given range of diets, it would then be necessary to describe what this ratio was for that kind of pig. This adds to the number of genetic variables needed to describe, sufficiently, a particular genotype (Emmans \& Fisher, 1986; Emmans \& Oldham, 1988), in order to predict the above responses. 
An alternative approach towards an explanation is to assert that pigs always give an absolute priority to gaining protein rather than lipid, provided only that there are sufficient lipid reserves in their bodies. The finding that the rate of protein retention can be increased by increasing the energy supply at a constant rate of protein supply, is then explained by asserting that the material efficiency with which the pig can retain protein is a function of the composition of the diet, in particular of its metabolizable energy:digestible crude protein ratio, $R$. It has been shown by Kyriazakis \& Emmans (1992a, b) how such a hypothesis can account for the findings mentioned earlier, provided that the relationship between $R$ and the efficiency of using the scarce protein supply above maintenance, $e_{p}$, is such that $e_{p}$ is directly proportional to $R$, with $e_{p}=k \times R$.

With this kind of explanation it is also possible that the constant of proportionality, $k$, is a genetic variable, but it was proposed a priori, partly for the sake of simplicity, that there would be no genetic effects on the value of $k$. To test the propositions (1) that $e_{p}$ is directly proportional to $R$ and (2) that $k$ does not differ between genotypes, an experiment was carried out on Large White $\times$ Landrace and Chinese Meishan pigs. These two genotypes differ considerably in many respects including their propensity to fatten and their potential (maximum) rates of protein retention (Haley et al. 1992; Kyriazakis et al. 1993).

\section{MATERIALS AND METHODS \\ Animals and housing}

Forty-eight entire male pigs, twenty-three F1 hybrid Large White $\times$ Landrace $(\mathrm{LW} \times)$ from the Pig Improvement Company (PIC; Abington, Oxfordshire) and twenty-five purebred Chinese Meishan (CM; PIC), were moved immediately after weaning (at 4 weeks of age) into the individual cages of the experimental unit, which has been described previously (Kyriazakis \& Emmans, 1992a). The two breeds were housed in two separate rooms of the unit. The weaned $\mathrm{LW} \times$ and CM pigs had a mean live weight of 8.83 (SD 0.35) $\mathrm{kg}$ and 8.43 (SD 1.35$) \mathrm{kg}$ respectively, and were given free and continuous access to a high-quality commercial feed (300 Ultra start pellets; Dalgety Agriculture Ltd; Bristol).

\section{Experimental feeds and design}

A basal feed (P) with an estimated energy content of 11.95 MJ metabolizable energy $(\mathrm{ME}) / \mathrm{kg}$ and $426 \mathrm{~g}$ crude protein $(\mathrm{CP}) / \mathrm{kg}$ was formulated (Table 1 ). The feed was overabundant in minerals and vitamins, as defined by the Agricultural Research Council (1981) in order to maintain similar mineral:protein ratios to those of a commercial grower feed. Comparison of the amino acid contents of feed $\mathbf{P}$ (Table 2) with that of the ideal protein proposed by the Agricultural Research Council (1981) showed that lysine was the first limiting amino acid.

As each pig reached $13 \mathrm{~kg}$ live weight it was assigned either to an initial slaughter group ( $n$ 11; five $\mathrm{LW} \times$ and six CM pigs) or to one of six feeding treatments $(1-6 ; n 6$ per treatment). On each feeding treatment half of the pigs were $\mathrm{LW} \times$ and half $\mathrm{CM}$. One extra CM pig was allocated to treatment 6.

The six feeding treatments were the combination of two allowances of the basal food, high (treatments 1-4) and low (treatments 5 and 6), and six levels of starch intake (Table 3 ). Treatments 5 and 6 were designed to allow the maximum efficiency of the use of protein to be observed as on these treatments the pigs had a low protein allowance coupled with high energy allowances. The other four treatments were chosen, in the light of the results of Kyriazakis \& Emmans (1992a,b), as those most likely to allow the relationship between feed composition, $R$, and efficiency, $e_{p}$, to be defined. The combinations used resulted in six 
Table 1. The composition and chemical analysis of the basal feed $P(\mathrm{~g} / \mathrm{kg}$ fresh feed $)$

\begin{tabular}{lc}
\hline \hline Ingredient (g/kg) & $196 \cdot 55$ \\
Wheat feed & $429 \cdot 00$ \\
Hipro soya-bean meal & $285 \cdot 00$ \\
Fish meal (Seapak 66) & $10 \cdot 00$ \\
Soya-bean oil & $2 \cdot 20$ \\
Threonine & $3 \cdot 00$ \\
Limestone & $16 \cdot 00$ \\
Dicalcium phosphate & $3 \cdot 25$ \\
Salt & $5 \cdot 50$ \\
Optivite Pig Wean (vitamin and mineral supplement) & $50 \cdot 00$ \\
Wood fibre & \\
Component (g/kg) & 891 \\
Dry matter & 426 \\
Crude protein $(\mathrm{N} \times 6 \cdot 25)$ & 75 \\
Crude fibre & 45 \\
Diethyl ether extract & 101 \\
Ash & $21 \cdot 4$ \\
Calcium & $13 \cdot 4$ \\
Phosphorus & 48 \\
Starch & $17 \cdot 39$ \\
Gross energy $(\mathrm{MJ} / \mathrm{kg})$ & $11 \cdot 95$ \\
Metabolizable energy $(\mathrm{MJ} / \mathrm{kg})^{*}$ & \\
\hline
\end{tabular}

* Calculated using the European Association of Animal Production Working Group equation (Batterham, 1990).

Table 2. The amino acid composition of the basal feed $(\mathrm{g} / \mathrm{kg}$ crude protein $(N \times 6 \cdot 25) ; C P)$

\begin{tabular}{lr}
\hline Alanine & $53 \cdot 6$ \\
Arginine & $68 \cdot 1$ \\
Aspartic acid & $73 \cdot 1$ \\
Cystine & $35 \cdot 2$ \\
Glutamic acid & $155 \cdot 8$ \\
Glycine & $96 \cdot 7$ \\
Histidine & $22 \cdot 2$ \\
Isoleucine & $35 \cdot 3$ \\
Leucine & $65 \cdot 7$ \\
Lysine & $51 \cdot 8$ \\
Methionine & $13 \cdot 1$ \\
Methionine + cystine & $48 \cdot 3$ \\
Phenylalanine & $38 \cdot 5$ \\
Serine & $55 \cdot 6$ \\
Threonine & $40 \cdot 2$ \\
Tryptophan & $12 \cdot 2$ \\
Tyrosine & $22 \cdot 9$ \\
Valine & $44 \cdot 6$ \\
\hline
\end{tabular}

values of $R$, the ME: digestible CP (DCP) ratio ranging from 33 to $119 \mathrm{MJ} \mathrm{ME} / \mathrm{kg} \mathrm{DCP}$. The allowances of both starch and feed $P$ were changed weekly on linear scales. The two feeds were mixed very thoroughly in a food mixer before they were offered as a mash. The lowest allowances of $\mathrm{LW} \times$ pigs were chosen to ensure that they would not be cold, and the highest ones as those expected just to give no refusals. The allowances of the $\mathrm{CM}$ pigs were set at 0.75 of those of the $\mathrm{LW} \times$ ones. In a previous experiment (Kyriazakis et al. 1993) both types of pig had been fed ad lib. On the treatments giving the highest rates 
Table 3. The allowances* of feed $P$ and starch on six feeding treatments for Large White $\times$ Landrace pigs $\dagger$

\begin{tabular}{|c|c|c|c|c|c|}
\hline \multirow{3}{*}{$\begin{array}{l}\text { Feeding } \\
\text { treatment }\end{array}$} & \multirow{3}{*}{$\begin{array}{c}\text { Allowance } \\
\text { of } P\end{array}$} & \multicolumn{4}{|c|}{ Feed intake $(\mathrm{g} / \mathrm{d})$} \\
\hline & & \multicolumn{2}{|c|}{ Week 1} & \multicolumn{2}{|c|}{ Week 6} \\
\hline & & Feed P & Starch & Feed $\mathrm{P}$ & Starch \\
\hline 1 & $\mathrm{Pl}$ & 400 & 0 & 900 & 0 \\
\hline 2 & & 400 & 100 & 900 & 225 \\
\hline 3 & & 400 & 200 & 900 & 450 \\
\hline 4 & & 400 & 300 & 900 & 675 \\
\hline 5 & $\mathrm{P} 2$ & 200 & 400 & 450 & 900 \\
\hline 6 & & 200 & 500 & 450 & 1125 \\
\hline
\end{tabular}

* In all treatments, allowances for the Chinese Meishan pigs were 0.75 times those for the Large White $\times$ Landrace pigs. All allowances were increased weekly on linear scales.

$\dagger$ For details of diet composition, see Tabje 1.

of protein retention the CM pigs gained $100 \mathrm{~g} / \mathrm{d}$ and the $\mathrm{LW} \times$ pigs $137 \mathrm{~g} / \mathrm{d}$. The ratio of the two rates is 0.73 , which was rounded to 0.75 . Had the $\mathrm{CM}$ pigs been given the same allowances as the $\mathrm{LW} \times$ pigs their rate of protein retention may well not have been limited by the protein supply and, hence, their net efficiency in using protein could not have been estimated.

The experiment lasted for 6 weeks from $13 \mathrm{~kg}$ live weight; at the end of the experiment all pigs were slaughtered and their bodies analysed chemically.

\section{Management and slaughter procedures}

The management and slaughter procedures were similar to those described in the previous experiment (Kyriazakis \& Emmans, 1992a). Pigs were fed twice daily (at 09.00 and 17.00 hours) and weighed weekly before feeding. Effort was made to collect any feed spillage on trays under the feed troughs. Feed refusals were collected and weighed daily and amounts of feed equivalent to the refusal and the estimated spillage refed later to the animals in addition to their set allowances. On the forty-second day of the experiment the pigs were fed normally, and on the following morning were weighed and killed by an injection of Pentobarbitol sodium. Their empty bodies were analysed for dry matter (DM), and the N, ash and gross energy (GE) contents of the DM.

The air temperature was gradually reduced from $28^{\circ}$ when the pigs were first moved, to $22^{\circ}$ or $24^{\circ} 2$ weeks later (the start of the experiment) for the $\mathrm{LW} \times$ and $\mathrm{CM}$ pigs respectively. The slightly higher temperature for the $\mathrm{CM}$ pigs was set to ensure that they would not be cold, given their lower feed allowances. However, some consistent feed refusals by the $\mathrm{CM}$ pigs on the highest allowances suggested that some of these pigs were perhaps hot. The temperature in the room where the CM pigs were kept was then also reduced to $22^{\circ} 2$ weeks after the start of the experiment. It was thereafter held constant at $22^{\circ}$ for all pigs.

\section{Analysis of the results}

Whenever there were some cumulative refusals of the offered diets these were measured and used in the analysis of the results. The results were analysed separately for the $\mathrm{LW} \times$ and $\mathrm{CM}$ pigs, since the conditions kept were not identical for the two breeds (including keeping them in separate rooms), by an analysis of variance as a randomized design with feeding 
treatment as a factor. The only direct comparisons made between the two breeds were those for the initial slaughter groups, the analysis of the chemical components of the empty body, and the relationship between the net efficiency of protein utilization and $R$.

The relationships between ash $(\mathrm{A})$, water $(\mathrm{H})$, and protein $(\mathrm{P})$ weights in $\mathrm{kg}$ were assumed to have the forms suggested by the Agricultural Research Council (1981). These are that $\mathrm{P}: \mathrm{A}$ and $\mathrm{H}: \mathrm{P}^{0 \cdot 855}$ are both constant. The data were used to estimate the values of the constants and to test for any breed and treatment effects.

The net efficiency of using the supply of ideal protein, above maintenance, for growth was calculated as in previous experiments (Kyriazakis \& Emmans, 1992a,b) from the equation:

$$
\mathrm{PR}=e_{p} \times\left(\left(\mathrm{FI} \times \mathrm{FCPC} \times \mathrm{v} \times \mathrm{d}_{\mathrm{cp}}\right)-\mathrm{MP}\right),
$$

where $P R$ is the rate of protein retention $(\mathrm{kg} / \mathrm{d})$ on a limiting feed eaten at the rate FI $(\mathrm{kg} / \mathrm{d})$ with a crude protein content of FCPC $(\mathrm{kg} / \mathrm{kg})$. The feed crude protein has a digestibility of $d_{c p}(\mathrm{~kg} / \mathrm{kg})$ and the digested protein a value in relation to ideal protein of $\mathrm{v}$. For feed $\mathrm{P}$ in Table 2 the values were calculated to be $d_{c p}=0.85$ and $v=0.74$ with lysine as the first limiting amino acid. The ideal protein needed for maintenance (MP) was taken to be $0.0040 \mathrm{P}(\mathrm{kg} / \mathrm{d})$ for both genotypes, where $\mathrm{P}$ is the pig's protein weight in $\mathrm{kg}$ (Whittemore, 1983).

The relationship between $e_{p}$ and $R$, the ME: DCP ratio of the food, was examined using the data from treatments $1-6$. The presumption was that the efficiency would be directly proportional to $R$. The two reasons for the presumption were: (1) this was the relationship reported by Kyriazakis \& Emmans $(1992 a, b)$ for two similar experiments, and (2) as was pointed out there, if the relationship is of this form a simple model follows. Nevertheless other possible forms for the relationship were tested.

As for the previous two experiments (Kyriazakis \& Emmans, 1992a,b), the lipid values used in the analysis were derived from the equation:

$$
\text { lipid }=(\mathrm{GE}(\mathrm{kJ} / \mathrm{g} \mathrm{DM}))-(23 \cdot 8 \times 6 \cdot 25 \times \mathrm{N}(\mathrm{g} / \mathrm{g} \mathrm{DM})) / 39 \cdot 6 \mathrm{~g} / \mathrm{g} \mathrm{DM} .
$$

\section{RESULTS}

Once the room temperature was reduced to $22^{\circ}$, after 2 weeks on the treatments for the CM pigs, feed refusals were mainly by the $\mathrm{LW} \times$ pigs on the two highest allowances of starch (treatments 5 and 6). Most of the refusals were successfully refed to the animals, but one LW $\times$ pig on treatment 6 finished the experiment having consumed only 0.89 of its total feed allowance. Managing the intakes of the refusing pigs was not easy and there was inevitably a higher level of feed wastage that could not be accounted for. This may well have affected the results apparently obtained for the LW $\times$ pigs on treatments 5 and 6 .

The compositions of the initial slaughter groups, at 13.04 and 12.83 (SED 0.422) kg live weight, were 12.03 and 11.75 (SED 0.355 ) kg empty body weight, 1.724 and 1.671 (SED 0.070) $\mathrm{kg}$ protein and 1.095 and 1.813 (SED 0.139 ) $\mathrm{kg}$ lipid for the $\mathrm{LW} \times$ and CM pigs respectively. The difference in lipid content of $0.718 \mathrm{~kg}$ between the two breeds was highly significant $(P<0.001)$. The compositions of the bodies of the $\mathrm{LW} \times$ and $\mathrm{CM}$ pigs killed after 6 weeks are shown in Table 4. Increasing the intake of starch at the higher allowance of feed $P(P 1)$ resulted in significant increases $(P<0.001)$ in the live weight and in the empty body, protein and lipid weights of both the $\mathrm{LW} \times$ and the CM pigs. However, the increase in the intake of starch at the low protein allowance (P2) did not affect the protein weights of these pigs; lipid weight continued to increase with increasing starch intake for both breeds.

The protein weight: ash weight ratio, including the data from the initial slaughter groups, was 5.18 (SE 0.072) with no appreciable, or significant, effects of either breed or treatment. 
Table 4. The live weight, empty body, protein and lipid weights of Large White $\times$ Landrace $(L W \times)$ and Chinese Meishan $(C M)$ pigs given two allowances of a high-protein feed (a high allowance, treatments $1-4$ and a low allowance, treatments 5 and 6 ) and six allowances of starch, at 6 weeks from $13 \mathrm{~kg}$ live weight $\dagger$

\begin{tabular}{|c|c|c|c|c|c|c|c|c|}
\hline \multirow[b]{2}{*}{ Treatment } & \multicolumn{2}{|c|}{$\begin{array}{c}\text { Live } \\
\text { weight }(\mathrm{kg})\end{array}$} & \multicolumn{2}{|c|}{$\begin{array}{l}\text { Empty body } \\
\text { weight }(\mathrm{kg})\end{array}$} & \multicolumn{2}{|c|}{$\begin{array}{c}\text { Protein } \\
\text { weight }(\mathrm{kg})\end{array}$} & \multicolumn{2}{|c|}{$\begin{array}{c}\text { Lipid } \\
\text { weight }(\mathrm{kg})\end{array}$} \\
\hline & LW $x$ & $\mathrm{CM}$ & $\mathrm{LW} \times$ & $\mathrm{CM}$ & $\mathrm{LW} \times$ & $\mathrm{CM}$ & $\mathrm{LW} \times$ & $\mathrm{CM}$ \\
\hline 1 & $25 \cdot 22$ & $19 \cdot 49$ & $22 \cdot 76$ & $17 \cdot 41$ & 3.994 & 2.988 & $0 \cdot 822$ & 1.797 \\
\hline 2 & $31 \cdot 30$ & $24 \cdot 13$ & $29 \cdot 11$ & $21 \cdot 65$ & 5.089 & $3 \cdot 726$ & $1 \cdot 569$ & $2 \cdot 135$ \\
\hline 3 & 33.92 & $27 \cdot 65$ & $31 \cdot 97$ & $25 \cdot 03$ & $5 \cdot 513$ & $4 \cdot 444$ & $2 \cdot 295$ & $2 \cdot 693$ \\
\hline 4 & $36 \cdot 44$ & $30 \cdot 07$ & $34 \cdot 15$ & $27 \cdot 33$ & $5 \cdot 844$ & $4 \cdot 709$ & $2 \cdot 859$ & $3 \cdot 320$ \\
\hline 5 & $27 \cdot 83$ & 23.66 & $25 \cdot 77$ & $22 \cdot 38$ & 3.916 & $3 \cdot 477$ & $4 \cdot 030$ & 3.930 \\
\hline 6 & $28 \cdot 34$ & $25 \cdot 73$ & $26 \cdot 40$ & $24 \cdot 05$ & $3 \cdot 895$ & 3.557 & $4 \cdot 719$ & 5.099 \\
\hline SED & 1.057 & 0.863 & 0.978 & $0-695$ & $0 \cdot 217$ & $0 \cdot 137$ & $0 \cdot 324$ & 0.230 \\
\hline $\begin{array}{l}\text { Statistical significance } \\
\text { treatment }\end{array}$ & $* * *$ & $* * *$ & $* * *$ & $* * *$ & $* * *$ & $* * *$ & $* * *$ & $* * *$ \\
\hline
\end{tabular}

Table 5. The daily rates of protein, lipid and gross energy $(G E)$ gains of Large White $\times$ Landrace $(L W \times)$ and Chinese Meishan $(C M)$ pigs when given two allowances of $a$ high-protein feed ( $a$ high allowance, treatments $1-4$ and a low allowance, treatments 5 and 6 ) and six allowances of starch, for 6 weeks from $13 \mathrm{~kg}$ live weight $\dagger$

\begin{tabular}{|c|c|c|c|c|c|c|}
\hline \multirow[b]{2}{*}{ Treatment } & \multicolumn{2}{|c|}{$\begin{array}{c}\text { Protein } \\
\text { gain }(\mathrm{g} / \mathrm{d})\end{array}$} & \multicolumn{2}{|c|}{$\begin{array}{c}\text { Lipid } \\
\text { gain }(\mathrm{g} / \mathrm{d})\end{array}$} & \multicolumn{2}{|c|}{$\begin{array}{l}\text { GE gain } \\
(\mathrm{MJ} / \mathrm{d})\end{array}$} \\
\hline & $\mathrm{LW} \times$ & $\mathrm{CM}$ & $\mathrm{LW} \times$ & $\mathrm{CM}$ & $\mathrm{LW} \times$ & $\mathrm{CM}$ \\
\hline 1 & 56 & 32 & -5 & 1 & $1 \cdot 13$ & $0 \cdot 81$ \\
\hline 2 & 82 & 50 & 13 & 9 & $2 \cdot 45$ & 1.55 \\
\hline 3 & 92 & 67 & 30 & 22 & $3 \cdot 38$ & $2 \cdot 48$ \\
\hline 4 & 100 & 73 & 43 & 37 & $4 \cdot 10$ & $3 \cdot 22$ \\
\hline 5 & 54 & 44 & 71 & 52 & $4 \cdot 11$ & $3 \cdot 10$ \\
\hline 6 & 54 & 46 & 88 & 80 & $4 \cdot 75$ & $4 \cdot 25$ \\
\hline SED & $5 \cdot 2$ & $3 \cdot 3$ & $7 \cdot 7$ & $5 \cdot 5$ & $0 \cdot 25$ & $0 \cdot 19$ \\
\hline $\begin{array}{l}\text { Statistical significance of } \\
\text { treatment }\end{array}$ & $* * *$ & $* * *$ & $* * *$ & $* * *$ & $* * *$ & $* * *$ \\
\hline
\end{tabular}

*** $P<0.001$

$\dagger$ For details of diets and procedures, see Table 1 and pp. $850-853$.

The mean values of the water:protein ratio raised to the 0.855 power (see p. 853 ) were $5 \cdot 27$ (SE 0.035) for the $\mathrm{LW} \times$ and 4.81 (SE 0.044) for the CM pigs; the two values were significantly different $(P<0 \cdot 001)$.

The daily rates of protein, lipid and GE deposition are shown in Table 5. The increase in the intake of starch resulted in significant $(P<0.001)$ increases in the rate of protein deposition of both $\mathrm{LW} \times$ and $\mathrm{CM}$ pigs given the higher allowance of feed $\mathrm{P}$. However, the increase in starch intake at the low protein allowance had no effect on the rate of protein deposition of the pigs $(54 v .54(\operatorname{SED} 5 \cdot 2) \mathrm{g} / \mathrm{d}$ and $44 v .46(\operatorname{SED} 3 \cdot 3) \mathrm{g} / \mathrm{d}$ for LW $\times$ and CM pigs respectively). The rates at which lipid and GE were deposited increased with each 
Table 6. The net efficiencies $(\mathrm{kg} / \mathrm{kg})$ of using ideal protein supply above maintenance for protein growth*

\begin{tabular}{|c|c|c|}
\hline Treatment & $L W \times$ & $\mathrm{CM}$ \\
\hline 1 & $0 \cdot 367,0 \cdot 289,0 \cdot 389$ & $0.269,0.227,0.308$ \\
\hline 2 & $0.513,0.482,0.547$ & $0.341,0.479,0.431$ \\
\hline 3 & $0.529,0.626,0.564$ & $0.576,0.581,0.547$ \\
\hline 4 & $0.610,0.617,0.652$ & $0.667,0.629,0.610$ \\
\hline 5 & $0 \cdot 706,0.740,0.712$ & $0 \cdot 782,0 \cdot 769,0.850$ \\
\hline 6 & $0.679,0.664,0.757$ & $0.815,0.867,0.807,0.871$ \\
\hline
\end{tabular}

* Data for individual pigs of Large White $\times$ Landrance $(\mathrm{LW} \times)$ and Chinese Meishan $(\mathrm{CM})$ breeds on the six feeding treatments described in Table 3.

increase in the level of starch intake (from treatment 1 to $6 ; P<0.001$ ) for both breeds. The rate of lipid deposition for pigs of both breeds on the lowest allowance of starch intake was not significantly different from zero.

The individual pig values for $e_{p}$ (see p. 853 for the calculation) are given in Table 6 , and plotted against the $R$ values of the diets in Fig. 1. Following the treatment of similar data used by Kyriazakis \& Emmans $(1992 a, b)$, the $e_{p}$ values were regressed on the $R$ values of the diets for treatments 1 to 6 using the data in Table 6 . The regression was:

$$
e_{p}=-0.0769(\operatorname{SE} 0.0548)+0.01241(\operatorname{SE} 0.00117) \times R(\operatorname{RSD} 0 \cdot 0552) .
$$

As the value of the intercept in equation (3) was small, and not statistically different from zero, and as it was expected that $e_{p}$ would be directly proportional to $R$, the intercept was set to zero and the regression through the origin calculated as:

$$
e_{p}=0.01081 \text { (SE 0.00024) } \times R(\mathrm{RSD} 0.0563) \text {. }
$$

The lower bound for $R$ is about $18 \mathrm{MJ} / \mathrm{kg}$ for a feed where all the energy comes from digested protein.

The quadratic regression of $e_{p}$ on $R$ and $R^{2}$, allowing an intercept, predicted that $e_{p}$ would have a maximum value of 0.643 when $R=65.1 \mathrm{MJ} / \mathrm{kg}$; this regression did not significantly reduce the residual sum of squares compared with that on $R$ alone with no intercept. The regression of $e_{p}$ on $\log _{\mathrm{e}} R$ did not significantly reduce the residual sum of squares either. The equation using all the CM data was:

$$
e_{p}=-1.139(\operatorname{SE} 0.115)+0.4199(\operatorname{SE} 0.0277) \times \log _{\mathrm{e}} R(\operatorname{RSD} 0.0573) \text {. }
$$

Of the regression models tried the one preferred a priori was, in terms of goodness of fit, no worse than any of the others tried.

The seven $\mathrm{CM}$ pigs on treatments 5 and 6 , which had $R$ values expected to be high enough for protein efficiency to be at its maximum, had a mean $e_{p}$ value of 0.824 . This was very close to the mean maximum value found in the experiments of Kyriazakis \& Emmans $(1992 a, b)$ of 0.813 for the males and females of Large White $\times$ Landrace pigs. The six $\mathrm{LW} \times$ pigs on these two treatments had a mean value of only 0.710 (Table 6 ). This aberrant result is, we believe, due to an artefact of the experimental method. The value used for feed intake in the calculation of the efficiency was an overestimate of the feed really eaten on these two treatments due to spillage that was observed but could not be recorded. There were feed refusals at some times by these pigs and, as described in the Methods section, an attempt was made to feed amounts equivalent to the refusals back to the pigs at a later time. On treatments at or near ad lib. levels this exacerbated the problem of wastage, but to an 


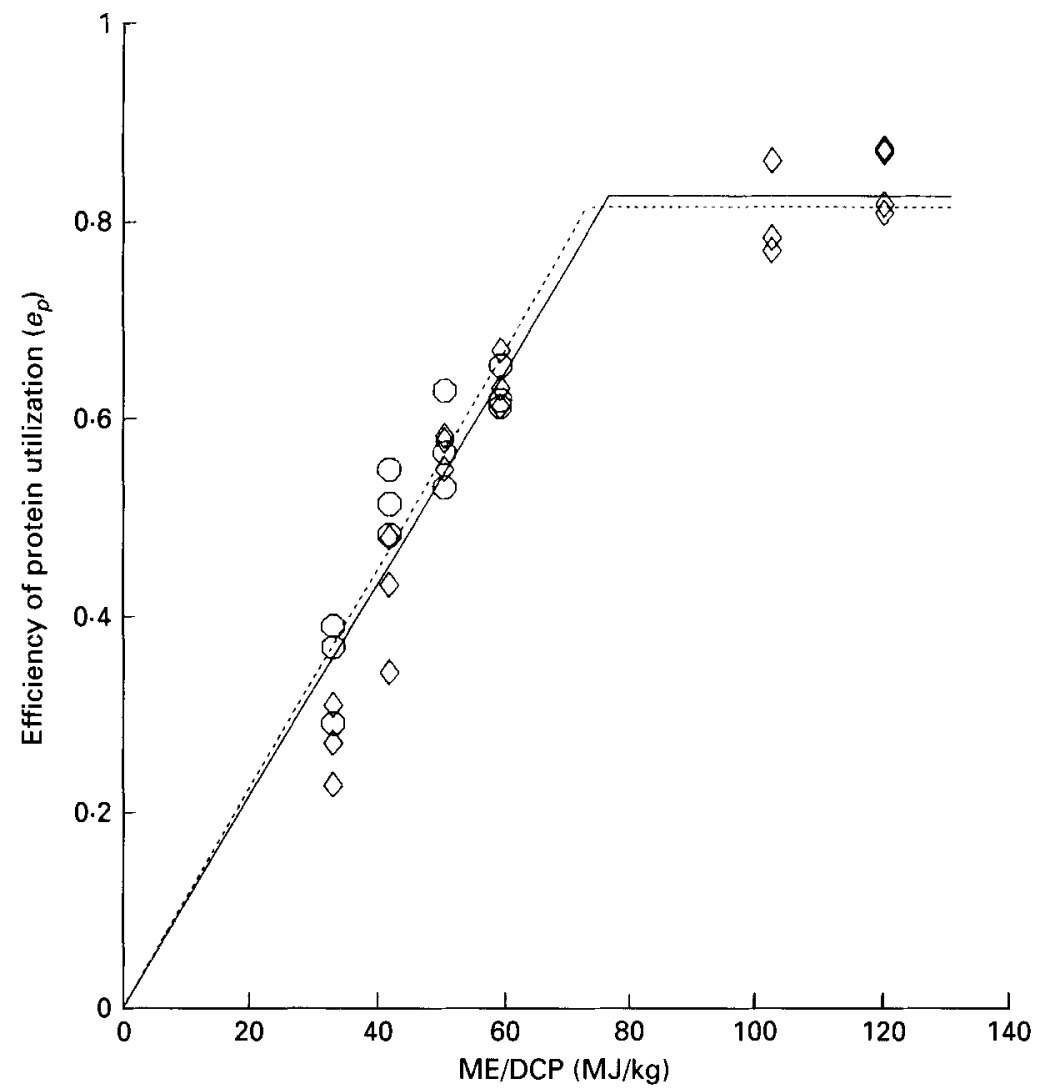

Fig. 1. The relationship between the efficiency of protein utilization, $e_{p}$, and $R$, the energy:protein ratio in the feed (MJ metabolizable energy (ME) $/ \mathrm{kg}$ digestible crude protein (DCP)) for Large White $\times$ Landrace $(O)$ and Chinese Meishan $(\diamond)$ entire male pigs. The regression equation for the ascending part of the relationship, shown as the solid line, was:

$$
e_{p}=0.0108(\mathrm{SE} 0.00024) \times R \text {, residual SD } 0.0563 .
$$

The dotted line represents the relationship between these two variables derived in the experiments of Kyriazakis \& Emmans $(1992 a, b)$ with Large White $\times$ Landrace entire male and female pigs. The regression equation for the ascending part of that relationship was:

$$
e_{p}=0.0112(\mathrm{SE} 0.00022) \times R \text {, residual SD } 0.0720 .
$$

unknown extent; feeding the diets of high starch content in the form of a mash did not help. The $\mathrm{LW} \times$ pigs, but not the $\mathrm{CM}$ pigs, alternated rapidly between feeding and drinking on these treatments with consequent increase in the physical loss of the mash feeds.

\section{DISCUSSION}

The two kinds of pig had virtually the same amounts of protein in their bodies at the start of the experimental period at a weight of $13 \mathrm{~kg}$, but the CM had twice the weight of lipid of the $\mathrm{LW} \times$. The lower water:protein ratio in the CM pigs reflected, at least in part, their higher degree of protein maturity at the same protein weight (Emmans, 1988), on the reasonable assumption that they would have a lower protein weight at maturity. Given the value of the exponent as 0.855 , in the power function relating water to protein proposed by the Agricultural Research Council (1981), and the values found for the two breeds, the 
water: protein ratios would be the same at maturity for both breeds if the $\mathrm{CM}$ pigs were to have a mature protein weight of 0.53 that of the $\mathrm{LW} \times$ pigs. It is also possible that these pigs would have a lower water: protein ratio at the same degree of protein maturity because of a greater proportion of their total protein in the skin and hair which are relatively dry tissues (Bonneau et al. 1990; Kyriazakis et al. 1993). The Agricultural Research Council (1981) value for the water:protein ${ }^{0.855}$ ratio is 4.89 , so that the value found here for the $\mathrm{LW} \times$ pigs of 5.27 was 1.08 times greater. De Greef et al. (1992) have also recently concluded that modern improved genotypes have more water at a given weight than that predicted by the equation of the Agricultural Research Council (1981).

The protein: ash ratio varied little around the mean value of $5 \cdot 18$, which is similar to the Agricultural Research Council (1981) value of $1 / 0 \cdot 189=5 \cdot 29$.

The CM pigs have slower growth rates and a lower capacity to deposit protein when given free and continuous access to a high-quality feed (Haley et al. 1992; Kyriazakis et al. 1993). They have also generally been seen to be fatter (Haley et al. 1992; Kyriazakis et al. 1993) and this was also observed in the initial slaughter groups here. The CM pigs can thus be seen as an unimproved breed of pig with a strong propensity to fatten, in marked contrast to the LW $\times$ pigs which have been selected for rapid growth and a low level of fatness. The two types of pig used were thus seen as being a hard test of any proposition that, in some sense, different breeds of pig would use the same rules to allocate a scarce resource between protein and lipid growth.

The $e_{p}$ values are plotted against the ME: DCP ratios of the diets in Fig. 1, with the values for the LW $\times$ pigs on treatments 5 and 6 omitted for the reasons given earlier (pp. 855-856). The regression line through the origin is shown together with that from the experiments of Kyriazakis \& Emmans $(1992 a, b)$. As can be seen from the data in Table 6, and from Fig. 1, the CM pigs appeared to have a lower efficiency than that predicted by the overall relationship on the most extreme diet, treatment 1 , which had the very high protein content of $426 \mathrm{~g} / \mathrm{kg}$ and only $11.95 \mathrm{MJ} \mathrm{ME} / \mathrm{kg}$.

There are three possible reasons for the CM pigs apparently having a lower efficiency of protein retention on treatment 1 . First, as asserted earlier (p. 850), the CM pigs on their lower absolute energy allowances could have reached a minimum lipid:protein ratio in their bodies. But, in fact, as can be seen from the data in Table 4, the CM pigs were fatter at the end of the experiment on treatment 1 than were the $L W \times$ pigs; therefore this cannot be an explanation. Second, the $e_{p}$ values for the CM pigs would have been higher had their MP values been taken to be higher than those for the $\mathrm{LW} \times$ pigs. It is likely, as discussed by Emmans \& Fisher (1986), that the maintenance coefficient for pigs of a lower mature protein weight should be higher than that for pigs of larger mature size. Allowing for this effect would have increased the $e_{p}$ values for the CM pigs somewhat, but the effect is not great. If the maintenance coefficient were to be doubled for the $\mathrm{CM}$ pigs the mean value for $e_{p}$ on treatment 1 would increase from 0.268 to 0.290 . Third, and possibly of greater importance, is the effect of the assumption that the amino acid composition of the protein ideal for growth is the same for both breeds despite the far greater proportion of the total protein in the skin and the hair in the CM pigs (Bonneau et al. 1990). The proteins of these two tissues are particularly rich in cystine. It is possible, therefore, that the first limiting amino acid in the feed protein for these pigs was the total of the sulphur-containing amino acids rather than lysine as was calculated using the composition of the ideal protein given by the Agricultural Research Council (1981). This possibility was not tested directly but it and the higher maintenance coefficient would both have operated in the direction needed to make the $e_{p}$ values of the CM pigs appear to be somewhat lower than those for the $\mathrm{LW} \times$ pigs on treatment 1 .

The maximum mean value of $e_{p}$ seen on treatments 5 and 6 for the CM pigs in this 
experiment of 0.824 was virtually identical to the value seen in the experiments of Kyriazakis \& Emmans $(1992 a, b)$ of 0.813 for the males and females of $\mathrm{LW} \times$ pigs. It would appear that there is no reason to expect any inherent difference in this maximum efficiency between genotypes. The aberrant result is that for the $\mathrm{LW} \times$ pigs in the current experiment which appeared to have a maximum efficiency of only 0.710 , as given in Table 6 . For the reasons given earlier (pp. 855-856) we believe that this figure is an artefact due to feed spillage. It would be odd if the maximum efficiency were to be different between the two kinds of $\mathrm{LW} \times$ pigs used in the present and earlier experiments while being virtually the same for the CM pigs used in the present experiment and for the $L W \times$ pigs used in the earlier ones.

The results are not directly comparable with those of other experiments where the responses of different pig genotypes to restricted supplies of protein have been measured. In the other experiments the treatments were two or more levels of feeding of a single feed. Such experiments in the literature are inconsistent with each other. Those of Fuller et al. (1982) and of de Greef et al. (1992), in which genotypes with different potential rates of protein retention were given the same limiting rate of feeding, showed the same rates of protein deposition. The genetically selected pigs of Ellis et al. (1983) had greater protein weights than the unselected pigs after being given the same rate of feeding for the same time, but the differences, although formally significant, were almost trivially small. The results of the experiment of Campbell \& Taverner (1988) on pigs from 45 to $90 \mathrm{~kg}$ live weight are very different, with the rates of protein retention in three kinds of pigs (improved boars, unimproved boars and castrates) fed on the same live-weight-based feeding scale, giving very different rates of protein retention on limiting diets. At first sight these results are strongly in favour of there being different rules for allocating a scarce resource in different kinds of pigs or effects of live weight on these rules. However, there are two possible problems with the results of this experiment. First, the efficiency of using ideal protein for growth, when calculated in the same way as described here, was only 0.52 for the most efficient genotype in the experiment; for the least efficient the value was only 0.29. This a very large difference between that experiment and this. Second, the mean ash:protein ratio was only $0 \cdot 135$, which is an extremely low value compared with all other published estimates that we have seen (Doornenbal, 1971, 1972; Agricultural Research Council, 1981; Tullis, 1981; Kyriazakis \& Emmans, 1992a,b). Such a low ratio suggests that the feed used may not have been first limiting in protein but more probably in a mineral so that the experiment was not a protein experiment at all. This could account for the low efficiency seen even in the most efficient genotype.

The results of the experiment reported here, on entire male pigs of two very different kinds, together with the results of Kyriazakis \& Emmans (1992b), on entire male and female pigs of another improved kind, are consistent with the idea that for diets with less than a critical value of the energy: protein ratio the net efficiency of using ideal protein for growth is directly proportional to the energy: protein ratio. The results of Campbell et al. (1983) on entire male and female pigs are also consistent with this view.

As was shown by Kyriazakis \& Emmans $(1992 b)$, the assumed relationship between $e_{p}$ and MEC:DCPC leads to a simple model for predicting the rates of both protein and lipid retention in a pig of known genotype. This relationship, and the resulting model, needs to be further tested on different kinds of pig at greater degrees of maturity (which could help to clarify the problem presented by the data of Campbell \& Taverner, 1988), and such experiments are planned.

This work was supported by BOCM Pauls Ltd and the Chinese Meishan pigs were donated by the Pig Improvement Company. D.D. was on leave of absence from the Faculty of 
Agriculture, Aristotle University of Thessaloniki, Macedonia, Greece. The authors would like to acknowledge the technical assistance of D. H. Anderson, T. McHale and J. Fraser. Peter Ormel helped with the statistical analysis of the first draft.

\section{REFERENCES}

Agricultural Research Council (1981). The Nutrient Requirements of Pigs. Slough: Commonwealth Agricultural Bureaux.

Batterham, E. S. (1990). Prediction of the dietary energy value of diets and raw materials for pigs. In Feedstuff Evaluation, pp. 267-281 [J. Wiseman and D. J. A. Cole, editors]. London: Butterworths.

Bonneau, M., Mourot, J., Noblet, J., Lefaucher, L. \& Bidanel, J. P. (1990). Tissue development in Meishan pigs: muscle and fat development and metabolism and growth regulation by somatotropic hormone. In Symposium sur le Porc Chinois, pp. 203-213 [M. Molenat and C. Legault, editors]. Jouy-en-Josas, France: Institut National de la Recherche Agronomique.

Campbell, R. G. \& Taverner, M. R. (1988). Genotype and sex effects on the relationship between energy intake and protein deposition in growing pigs. Journal of Animal Science 66, 676-686.

Campbell, R. G., Taverner, M. R. \& Curic, D. M. (1983). The influence of feeding level from 20 to $45 \mathrm{~kg}$ liveweight on the performance and body composition of female and entire male pigs. Animal Production 36, 193-199.

Campbell, R. G., Taverner, M. R. \& Curic, D. M. (1985a). The influence of feeding level on the protein requirements of pigs between 20 and $45 \mathrm{~kg}$ liveweight. Animal Production 40, 489496.

Campbell, R. G., Taverner, M. R. \& Curic, D. M. (1985b). Effects of sex and energy intake between 48 and 90 $\mathrm{kg}$ liveweight on protein deposition in growing pigs. Animal Production 40, 497-503.

de Greef, K. H., Kemp, B. \& Verstegen, M. W. A. (1992). Performance and body composition of fattening pigs of two strains during protein deficiency and subsequent realimentation. Livestock Production Science 30 , $141-153$.

Doornenbal, H. (1971). Growth, development and chemical composition of the pig. I. Lean tissue and protein. Growth 35, 281-295.

Doornenbal, H. (1972). Growth, development and chemical composition of the pig. III. Bone, ash and moisture. Growth 39, 427-434.

Ellis, M., Smith, W. C., Henderson, R., Whittemore, C. T., Laird, R. \& Phillips, P. (1983). Comparative performance and body composition of control and selection line Large White pigs. 3. Three low feeding scales for a fixed time. Animal Production 37, 253-258.

Emmans, G. C. (1988). Genetic components of potential and actual growth. In Animal Breeding Opportunities. British Society of Animal Production Occasional Publication no. 12, pp. 153-181. Edinburgh: BSAP.

Emmans, G. C. \& Fisher, C. (1986). Problems in nutritional theory. In Nutrient Requirements of Poultry and Nutrition Research. Poultry Symposium no. 19, pp. 9-39. [C. Fisher and K. N. Boorman, editors]. London: Butterworths.

Emmans, G. C. \& Oldham, J. D. (1988). Modelling of growth and nutrition in different species. In Modelling of Livestock Production System, pp. 13-21 [S. Korver and J. A. M. van Arendonk, editors]. Dordrecht : Kluwer Academic Publishers.

Fuller, M. F., Gordon, J. C. \& Aitken, R. (1982). Energy and protein utilisation of pigs of different sex and genotype. In Energy Metabolism of Farm Animals. European Association of Animal Production Publication no. 29, pp. 169-174. Switzerland: Vitznan.

Haley, C. S., d'Agaro, E. \& Ellis, M. (1992). Genetic components of growth and ultrasonic fat depth traits in Meishan and Large White pigs and their reciprocal crosses. Animal Production 54, 105-115.

Kyriazakis, I. \& Emmans, G. C. (1992a). The effects of varying protein and energy intakes on the growth and body composition of pigs. 1. The effects of energy intake at constant, high protein intake. British Journal of Nutrition 68,603-613.

Kyriazakis, J. \& Emmans, G. C. (1992b). The effects of varying protein and energy intakes on the growth and body composition of pigs. 2. The effects of varying both energy and protein intake. British Journal of Nutrition 68, 615-625.

Kyriazakis, 1., Leus, K., Emmans, G. C., Haley, C. S. \& Oldham, J. D. (1993). The effect of breed (Large White $\times$ Landrace $v$. purebred Meishan) on the diets selected by pigs given a choice between two foods that differ in their crude protein contents. Animal Production 56, 121-128.

Tullis, J. B. (1981). Protein growth in pigs. PhD Thesis, University of Edinburgh.

Whittemore, C. T. (1983). Development of recommended energy and protein allowances for growing pigs. Agricultural Systems 11, 159-186. 